\title{
How Do Natural Gas, Oil, and Coal Consumption Contribute to Environmental Degradation? An Empirical Investigation in Russia
}

\section{Orazaliyev Kanat}

Beijing Institute of Technology

\section{Zhijun Yan}

Beijing Institute of Technology

Muhammad Mansoor Asghar

Beijing Institute of Technology

\section{Zahoor Ahmed}

Beijing Institute of Technology

\section{Haider Mahmood}

Prince Sattam bin Abdulaziz University

\section{Dervis Kirikkaleli}

European University of Lefke

Muntasir Murshed ( $\nabla$ muntasir.murshed@northsouth.edu )

North South University https://orcid.org/0000-0001-9872-8742

\section{Research Article}

Keywords: Natural gas, Economic growth, Coal consumption, Environmental sustainability, CO2 emissions

Posted Date: July 27th, 2021

DOl: https://doi.org/10.21203/rs.3.rs-673735/v1

License: (c) (1) This work is licensed under a Creative Commons Attribution 4.0 International License. Read Full License

Version of Record: A version of this preprint was published at Environmental Science and Pollution Research on August 19th, 2021. See the published version at https://doi.org/10.1007/s11356-021-159897. 


\section{Abstract}

Environmental degradation sourced by conventional energy sources is not only a major factor behind climate change but also poses an adverse impact on human health. Undoubtedly, fossil fuels are major drivers of economic growth; however, their detrimental environmental impacts are of global scope, affecting the inhabitants of the whole world. In the literature, there is no comprehensive empirical evidence on the linkage between different energy sources and $\mathrm{CO}_{2}$ emissions in Russia which is among the top five $\mathrm{CO}_{2}$ emitting nations. Thus, this paper aims to quantify the relationships between oil consumption, natural gas consumption, coal consumption, and $\mathrm{CO}_{2}$ emission controlling economic growth in Russia. The findings indicate that $\mathrm{CO}_{2}$ emissions in Russia are cointegrated with oil, gas, coal, and economic growth. The long-run outcomes unfold that Russian economic growth is not directly harmful to environmental quality; however, the consumption of oil, gas, and coal upsurge the level of $\mathrm{CO}_{2}$ emissions. In addition, we conducted Granger causality tests for causal interaction analysis. The findings on the Russian data confirm the existence of both long and short-term causal connections with the country's economic growth, disaggregated fossil fuel consumption, and $\mathrm{CO}_{2}$ emissions. In conclusion, we directed several policy recommendations to address the challenges and threats posed by energy-related emissions without adversely impacting economic growth in Russia. These policies could also be advantageous to other countries, especially those with close Russian links.

\section{Introduction}

Environmental degradation, produced by the consumption of fossil fuel energy, poses a serious climatic and environmental challenge, especially considering the damaging effects of $\mathrm{CO}_{2}$ emissions on the health of human beings (Ozturk and Acaravci 2010; Al Mamun et al. 2014; Salahuddin et al. 2018). Earlier and current literature confirm these adverse environmental effects, which increase the prevalence of certain diseases and the human mortality rate (Elisa et al. 2020; Lalesca et al. 2020). Currently, the overuse of fossil fuels not only threatens the quality of life, but also contributes to environmental degradation and, consequently, to increases in health expenditures (Wang et al. 2019a). Moreover, related literature produced by various scholars (Liu et al. 2017; He et al. 2020; Requia et al. 2018; Gao et al. 2018; Wang et al. 2019b) confirms that $\mathrm{CO}_{2}$, a greenhouse gas primarily produced by human activities, not only contributes to global warming but is a cause of damage to the earth's atmosphere, ocean, land surface, plants, microorganisms, animals, and health of people. Therefore, it is unrealistic to disregard the effect of $\mathrm{CO}_{2}$ emissions produced by fossil fuel consumption for purposes of economic growth.

This investigation targets to research the connection between and influence of respectively natural gas consumption, coal consumption, oil consumption, economic growth, and $\mathrm{CO}_{2}$ emissions in Russia. Fossil fuels are non-renewable energy resources and burning up of fossil fuels is responsible for the increase in temperature and worsening of the environment (Chen et al. 2019). Some studies (Abas et al. 2017; Wang et al. 2019c) suggest that environmental pollution stemming from the utilization of fossil fuels contributes to $65 \%$ of global air pollution, also considering that studies dating back nearly three decades 
(Kwiatkowski and Phillips 1992) claimed that petroleum and gas are the strongest emitting agents in the world. Various scholars, using time series and panel data on different countries at various points in time, have considered the harmful correlation between human health and usage of oil, gas and coal, and identified $\mathrm{CO}_{2}$ emissions and the subsequent environmental pollution as the major cause of the resulting environmental and health crises.

These studies include those done on Pakistan, covering the 1970-2016 period and using ARDL (Anees et al. 2018; Rasool et al. 2019), and on 15 Asian countries (Hanif et al. 2019). Additional contributions were those on 1990-2013 data using the ARDL model, (Gorus and Aydin 2019), in MENA countries, using 19752014 data and vector regression, and on France, covering the 1980-2015 period and also using the ARDL model (Kibria et al. 2019). The latter identified two causal connections between the utilization of fossil fuels and pollution of air, and the harmful impact of this connection on economic development and human health. Based on these empirical studies, it is evident that the negative externalities stemming from the utilization of energy sources, specifically oil, gas, and coal, cannot be ignored any longer.

A plethora of literature is also available on the relationships between economic development and energy use over the past decades (Ozturk et al. 2010; Tang et al. 2016). The recent empirical research by Waheed et al. (2019) provides evidence that although utilization of oil, natural gas, and coal plays an important part in economic growth, it causes air pollution. Moreover, studies on 30 OECD countries (Ouyang et al. 2019), on China, using Spatial autocorrelation and Moran's I index (Yue et al. 2019), on Pakistan using data for the 1971-2014 period (Baz et al. 2019), and on African examples (Hanif et al. 2018), all confirmed a two-way causal connection between utilization of oil, gas, coal, economic growth, and air pollution. However, in the context of a major economy (Russia), empirical studies on the cointegration and causal association of various fossil fuels, economic growth, and emissions are scant. Hence, concerning Russia, empirical studies on this nexus are required to produce new findings and practical policy implications.

The coal, oil, and gas industry occupy a strategic position and plays a crucial role in Russia's economic growth, even though environmental issues caused by fossil fuels are not seriously considered in the Russian context in the previous literature. Neglecting environmental issues allow growing environmental deterioration in Russia (Shvarts et al. 2016). As far back as 2007, according to Pao et al. (2011), Russia has now contributed 5.01 percent of the world's overall $\mathrm{CO} 2$ emissions and became the third-largest greenhouse gas emitter in the world, behind China and the United States. Being one of the largest global suppliers and consumers of fossil fuels, Russia is pivotal to the entry into force and effectiveness of the Kyoto Protocol as an international climate policy framework (Korppoo et al. 2020). Furthermore, since fossil energy has been the main driver of Russia's industrial revolution, it also influences technological, social, economic, and development progress (Orazalin and Mahmood 2018). Also, it is a vital source of carbon emissions and GHG emissions (Boussalis et al. 2016).

The United Nations Climate Summit from September to December 2014 at the 20th Conference of the Parties to the UNFCCC in Lima (Peru), set a 25-30\% reduction target for GHG emissions. Using 1990 levels 
as a basis, this should set the world on the way to low-carbon developments compatible with the longterm objective of keeping the rise in the earth's temperature below 2 degrees Celsius by 2030 (2015a INDC). According to previous literature, the rates of economic growth and related utilization of energy are among the essential reasons for increased $\mathrm{GHG}$ and $\mathrm{CO}_{2}$ emissions and have, at least over the past two decades, been a subject of discussion among scientists and politicians (Kivyiro and Arminen 2014). Nonetheless, although the fossil fuel energy consumption of Russian industries has resulted in a significant transformation of its $\mathrm{CO}_{2}$ emissions profile, it continues to cause extensive damage to the Russian environment.

This study aims to research the nexus and influence of oil consumption, natural gas consumption, coal consumption, economic growth, and $\mathrm{CO}_{2}$ emissions in Russia. It is diverged from prior work and adds to the prevailing works in diverse ways. First, the study investigates the connection between disaggregated fossil fuels, and $\mathrm{CO}_{2}$ in Russia controlling economic growth which to the knowledge of the authors, have not been investigated previously. Second, it estimates the long-run, short-run, and causal associations between variables for a period of 1990 to 2016 that coincides with a significant increase in fossil fuel usage. Third, in a holistic manner, the study makes wide-ranging and inclusive policy recommendations to decrease $\mathrm{CO}_{2}$ emissions without compromising economic growth.

The remaining five sections of this study, in sequence, respectively supply an overview of the relevant literature; clarify the background theory and model particulars; indicate the econometric strategy and method of data collection; present and explains the empirical outcomes; and finally, suggest policy implications.

\section{Literature Review And Theoretical Background}

Many empirical studies covering various regions of the world, time spans, variables, and statistical tools, have been done on the environmental effect of the utilization of energy, economic development, and pollution. Their divergent findings have been documented in econometric energy literature, among others by Saboori and Sulaiman (2013a) in an analysis on the correlation among growth, energy, and pollution in Malaysia from 1980 to 2009, who confirmed that although economic growth depends on energy consumption, the environmental degradation it causes contributes significantly to and increases global warming. Similar significant results on the energy, growth, and air pollution nexus were confirmed by Saidi and Hammami (2015) in respect of 58 Sub-Saharan countries (Heidari et al. 2015 and Valadkhani et al. 2019a).

Moreover, the main causes of air pollution (particularly carbon and GHG emissions) reside in the population, gross domestic production (GDP), and energy systems. Researchers like Lin and Raza (2019) and Wang et al. (2019) reported that GHG is the most prominent cause of air pollution. Not only does it deteriorate the environment, which on its part influences human health, but it also provides a dynamic nexus between respectively economic growth health expenditure and $\mathrm{CO}_{2}$ emissions. Furthermore, like 
others, they confirmed and explained the structural differences in economic development, $\mathrm{CO}_{2}$, and health expenditure in Pakistan.

To protect the environment by reducing emissions, effective policies are required for the prevention and reduction of air pollution. In addition, other researchers investigating the positive links between economic growth and $\mathrm{CO}_{2}$ observed that the correlation of these variables varied significantly from low to highincome countries. This and related research on the impact of economic development, urbanizations, and deep-polluting fossil fuels on air pollution also indicate that the connection between these factors and air pollution is dynamic and that they change continuously.

In addition, several studies focused on the field of transport. He et al. (2005), in respect of China, explored the changes in energy consumption pertaining to the road transport sector's air pollution, predicted oil consumption, and carbon emissions trends, and subsequently proposed related policy changes to control excessive increases in oil consumption. Similar research on Pakistan highlighted the impact on air pollution of heavy-duty trucks used in the transportation industries (Rasool et al. 2019). Regarding Spain, Sanz et al. (2014) explored the role of biofuel use on pollutions decrease in the Spanish transport industry. In respect of Mexico, the study of Solís and Sheinbaum (2013) measured the impact of gasoline automobiles, light-duty freight carriers, diesel heavy-duty freight transporters, and diesel interurban buses on the road field of transport $\mathrm{CO}_{2}$ emissions, and identified that these categories of vehicles contributed respectively $32.6 \%, 25 \%, 12 \%$ and $11.3 \%$ to air pollution.

To extend and refine the literature review, the results of previous and current empirical research that statistically reflect the pairwise relationship of the studies main variables are subdivided into and discussed in terms of the following strands:

\subsection{Economic growth and fossil fuel}

From the aforesaid, it is evident that several authors, over time, focused on the first research strand, namely the linkages, respectively GDP growth and the utilization of fossil fuel energy, and used integrated approaches to solve the problems that emerged. Among others, Hanif et al. (2019) used the ARDL model to Asian countries by using data on the 1990-2013 period and confirmed that economic growth and usage of energy indeed contribute to the generation of air pollution. Although they were unable to establish a causative connection with the utilization of energy sources and economic development, they confirmed the unidirectional nexus among and influences the utilization of energy sources on economic development(Acheampong 2018).

Ahmad and Du (2017), using data on Iran for the 1971-2011 period, also researched the interrelationship of the utilization of energy, economic development, and $\mathrm{CO}_{2}$ and verified its positive effect of energy production on economic development. Other researchers evaluated the connections with energy, economic development, and $\mathrm{CO}_{2}$ in a wide range of states using different data sets. This included Kibria et al. (2019) who covered 151 nations, analyzing data for the 1971-2013 period; Mensah et al. 
(2019) who compared 22 African nations, evaluating data on the 1990-2015 interval; Mohamed et al. (2019) who analyzed the situation in France, by using data on the 1980-2015 period; and Asafu-adjaye et al. (2016) who compared 53 states, using data on the 1990-2012 period. The results of these studies confirm the long-term nexus with the utilization of energy sources and economic development, and that energy use has a strong positive influence on economic development over the long term.

\subsection{Coal consumption and carbon emissions}

The following research strand in the research literature has coal production and consumption as a point of departure. According to statistics reported by the public company, British Petroleum, in 2012, coal energy already occupied a pivotal position in global energy as the main source of energy usage and pollution of air (29.9\%) (Lei et al. 2014). Some scholars (Zhang et al. 2019; Chai et al. 2019) - in the field of China is the most end-user of the coal on the globe and contributor to growth in global coal production after the Asia Pacific region, Europe, Eurasia, and North America, and using data on the variables of economic development and coal consumption for the 1965-2016 period - systematically analyzed, measured and aggregated the impact of various factors as seen from different perspectives, in order to determine their combined effect as a basis to reduce coal consumption.

The proposed policy reforms, based on the related research on the use of coal as an energy resource, are conducive to $\mathrm{CO}_{2}$ emission reductions and should have environmental benefits. However, the impact thereof varies for different policy designs. For example, as a disincentive, tax increases inhibit resource consumption, improves resource utilization efficiency, and reduces haze damage, but the implementation of a resource value compensation policy, as an incentive, improves environmental quality and therefore has a beneficial effect on the standard of the environment. These political options relate to Russia, in particular, as a country with the world's second-largest coal reserves and resources. In 2016, Russia contributed about $4.5 \%$ of the world's coal production. In 2017, the total Russian coal production reached 408.1 million tons, an increase of 58.4\% since 2000 (Academy 2018). The coal resources and reserves are also widely distributed, and the country has 22 coal basins in the region and 129 separate deposits. The largest and also most industrially established area is the Kuznetsk Basin (Kuznetsov and llyushechkin), which is a major contributor to environmental damage worldwide. Hence, the negative effects of coal supply and consumption on the environment and the enduring damage caused by it are not only an inevitable outcome of the country's reliance on coal but also aspects that enhance the appropriateness of Russia as a research case study.

\section{$2.3 \mathrm{CO}_{2}$, oil and natural gas consumption linkages}

The third research strand focuses on the consumption of oil, gas, coal, and carbon emissions. The process of oil and natural gas extraction requires huge amounts of energy consumption, all of which negatively affect the environment, and this is primarily due to air pollution. This was confirmed by the studies of Alkhathlan and Javid (2013) on Saudi Arabia, using EKC regression and the ARDL model, covering the 1980-2011 period; of Bimanatya and Widodo (2018) on Indonesia, who applied the VECM 
(vector error correction model ) and Granger causality to the 1965-2012 period; and of Das et al. (2016) on India, using the Autoregressive Integrated Moving Average Model in respect of the 1966-2008 period. These studies confirmed and analyzed the existence of bidirectional relationships in oil and gas consumption-led emissions. These relationships also apply to Russia, being a large oil and gas producing and exporting country (more than approximately 10.83 million barrels) that produces $12 \%$ of the world's oil, with a corresponding proportional part of global oil exports (Overland 2017). The oil and gas production of the national companies is increasing rapidly, expanding oil and gas contribution to future pollution and environmental degradation (Bradshaw 2016). To this end, we investigate the extent to which energy consumption causes air pollution in Russia.

\section{$2.4 \mathrm{CO} 2$ emissions and economic growth}

In this fourth and final strand, the literature analyzes and finds out the ties between $\mathrm{CO}_{2}$ emissions and economic growth. As previously stated, the world's economic activities require the consumption of energy resources, also considering that this energy mainly derives from energy sources and results in $\mathrm{CO}_{2}$ emissions (Deutch 2017). The correlation between $\mathrm{CO}_{2}$ and economic growth is subject to ongoing and repeated academic research and is well-documented in econometric energy literature. Mardani et al. (2019) reviewed 175 studies among $\mathrm{CO}_{2}$ and economic development, the findings of which demonstrated the linkage of carbon pollutions and economic development when bidirectional causality is present. As economic development rises or sinks, corresponding higher or lower levels of $\mathrm{CO}_{2}$ emissions are measured, also considering that a reduction of the emissions could negatively impact economic growth. Both Wang et al. (2019b) and Saidi and Hammami (2015), based on analyses involving 58 countries over the 1990-2012 period and using a dynamic data panel model priced using the Generalized Moment Model (GMM), reported the impact of economic development and $\mathrm{CO}_{2}$ on the utilization of energy. Their empirical evidence confirms the major positive effect of $\mathrm{CO}_{2}$ emissions on the utilization of energy and the beneficial impact of economic development on the utilization of energy.

A body of related research supplements the aforesaid. Among others, Mikayilov et al. (2018) studied the connection with economic development and carbon emissions for Azerbaijan in the 1992-2013 period, using robust results produced by the application of Johansen, ARDLBT, DOLS, FMOLS, CCR methods. Their findings not only showed that the different co-integration methods are consistent with one another, but also that economic development has a beneficial effect on emissions. Furthermore, Gorus and Aydin (2019), adopting both a single and multi-country approach, concentrated on the causal link among energy consumption, economic development, and emissions of CO2. Their study of Granger causality, covering the period from 1975 to 2014 in respect of MENA countries, showed that utilization of energy sources causes economic development over the long term, whereas energy consumption is the short term Granger cause of $\mathrm{CO}_{2}$. In addition, it is common knowledge that, over the past few decades, global $\mathrm{CO}_{2}$ emissions played an important, central role in sustainable human development and environmental concerns. 


\section{Theoretical Support And Model Specification}

This part presents background information on the causal connection of fossil fuel energy consumption, economic growth, and $\mathrm{CO}_{2}$ emissions in Russia. As indicated in the literature review, previous research on various countries applied different research methods to analyze this relationship and produced divergent results. But, in the available research, the results and findings of these research endeavors are not final and require further investigation. For example, Akalpler and Hove (2019), in their research in India for the 1971-2014 period, used an ARDL model to analyze the annual data and to determine co-integration on the variables. Similarly, Rauf et al. (2018) also applied the ARDL model to generate a long and short-term estimation in China, spanning the 1968-2016 period. The literature, of both an academic and practical nature, also provides ample examples of the testing of and evidence on the influence of energy on economic development and on mitigation capacity of fuel substitution. In support, the results of related research involving the use of ARDL (Wesseh and Lin 2018; Fuinhas and Marques 2012) on the connection among main utilizations of energy and economic development in Turkey, Portugal, Greece, Italy and Spain covering the 1964-2009 period, show that all alternative fuel types can serve as substitutes and that a bidirectional nexus exists among them and GDP. Accordingly, our objective is to study the connection among the core variables, namely fossil fuel energy economic growth and $\mathrm{CO}_{2}$ emissions in Russia.

To realize this goal, we link the connection with economic growth and $\mathrm{CO}_{2}$ emissions through fossil fuel consumption. However, previous research produced mixed results on the relationship between these variables. Existing literature, in respect of many countries, confirms the direct connection between our variables. Accordingly, we regard fossil fuel energy and economic growth as the main independent variables and $\mathrm{CO}_{2}$ emissions as the dependent variable. Economic growth is measured by the annual rate of the log of real per capita GDP, also considering that an increase in real per capita GDP requires the use of fossil fuel energy and therefore causes carbon emissions. The extent of fossil fuel consumption, more specifically expressed as oil and gas, and coal consumption, is applied to research the impact of coal, oil and gas consumption on carbon emissions, and how this impact increases carbon emissions when consumption escalates (Hanif et al. 2019). To measure our variables, we use the linear model of the logarithm to obtain analytical observations, because our data (see below) are transformed into a logarithmic form as this gives more efficient, improved and consistent results.

Whereas $\mathrm{CO}_{2 \mathrm{t}-1}$ reflecting carbon emissions represents the dependent variable, log $\mathrm{GDP}_{\mathrm{t}-1}$ means gross domestic product to measure economic growth as the independent variable. Furthermore, log $\mathrm{Oil}_{\mathrm{t}-1}$ indicates oil consumption, $\log$ Coal $\mathrm{t}_{\mathrm{t}-1}$ indicates coal consumption, $\log \mathrm{NG}_{\mathrm{t}-1}$ refers to natural gas, and $\mu_{\mathrm{t}}{ }^{-1}$ expresses the error correction term. Table 1 presented information on the variables used in this research

\subsection{Econometric strategy and data collection}

To conduct this research, we used time-series data on the consumption of coal, oil gas and economic growth as the independent variables and on carbon emissions as the dependent variable - in respect of 
Russia covering the 1990-2016 period - obtained from the official World Bank (2017) web page on World Development Indicators. As indicated, similarly to several previous studies, we also used the ARDL model developed by Pesaran and Shin (1995); arguably one of the most important 20th-century contributions to solving the analysis of series using one co-integrating vector, also considering that it does not require pretesting of the unit root (Nkoro and Uko 2001a). The ARDL model, as indicated in the literature review and confirmed by the theoretical background, is popular and often used in the energy research field to deal with applications involving numerous variables (Nkoro and Uko 2001b), and to manage economic variables when working with time-series data.

Apart from its intrinsic value and advantages, we chose this method specifically based on the threefold justification provided by Ifa and Guetat (2018): First, the ARDL model is effective to execute the short and long-term connection amidst various variables which have a varying order of integration, on condition that these variables remain at a stationary level; that is I (0), and they are stationary in the first difference I (1). Second, it removes problems caused by omitted variables and auto-correlation. Third, it is an appropriate model to apply to small sample size. In addition, as Makun (2018) contends, the ARDL model does not require a preliminary check of the unit root test; considering that it is necessary to undertake this analysis in statistical testing to ensure that parameters do not present a unit root problem and that their integration order is always less than one.

The formulation of the formulas representing the ARDL approach is given below:

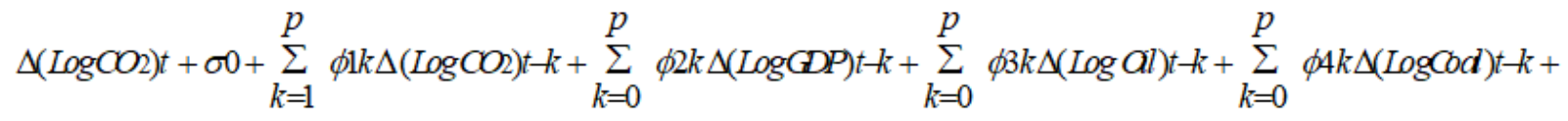

$$
\begin{aligned}
& \sum_{k=0}^{p} \phi 5 k \Delta(\log N G) t-k+\beta C \operatorname{CO}_{2}(\log C O 2) t-1+\beta G D P(\log G D P) t-1+\beta a l(\log O i l) t-1+\beta \operatorname{Cod}(\log \operatorname{Cod}) t-1+\beta N G(\log N G) t-1+\mu
\end{aligned}
$$

\section{Empirical Analysis And Discussion Of Results}

We used the well-known Augmented Dickey-Fuller (ADF) statistical test to determine whether the time series is stationary or non-stationary, depending on whether the above process has a unit root (Dickey et al. 2012). If statistical parameters such as variance and mean are constant over time, the result is a stationary time series. However, some properties are dependent on time, resulting in a non-stationary times series. Because of the latter, it is necessary to determine if a time series is stationary or not, using the ADF test, which is a type of unit root test. Since statistical properties dependency on time is a cause for non-stationarity, the tests will indicate if the unit root is present. As indicated in Table 2, the status of the variables is stationary at I (1) and 1(0). The closer examination of our findings confirmed that the ARDL model can be applied since variable are stationary at I (0) and I (I).

After the unit root ADF tests, we defined the co-integration of variables by means of ARDL bound testing. The findings of the ARDL bound test are summarized in Table 4. Since the F-statistics values are also 
within the higher limits, compared to the critical values for upper bounds, they similarly confirm the rejection of the null hypothesis of no co-integration.

\subsection{Long and short-term relationship estimation}

Following the unit root tests, we tested for co-integration using the ARDL bound testing approach for the long and short-run dynamics, thereby producing the results indicated in Table 5. This conclusion was supported by the Arch Test and Breusch-Godfrey test to diagnose serial correlation and heteroscedasticity, respectively, considering that the error term is the equivalent of white noise and can be ignored. We also used the Ramsey RESET check, which shows that the model is appropriately defined for this study.

According to Rasool et al. (2019b), the ARDL bound test is a well-known approach to test co-integration and is superior to the traditional co-integration approaches; it is suitable for long-term relationship between variables, is convenient for small sample estimations and for ECM (dynamic error correction model), it provides for linear transformation, and it can evaluate both long and short-term parameters.

Table 5 includes, first, the outcomes of the long-term coefficient of the ARDL model $\mathrm{CO}_{2}$ emissions. These measures indicate that the probability value is significant and that economic growth $(-0.010824)$ correlates negatively, but that consumption of oil $(0.154073)$, natural gas $(0.521699)$, and coal (0.430276) respectively has a significant positive impact on $\mathrm{CO}_{2}$ emissions with long-term relationships. What these findings indicate is that the higher consumption of coal, oil and gas, fertilizers, and fuel for other energy-intensive economic activities explains the relationship between economic growth and $\mathrm{CO}_{2}$ emissions. Although these energy resources stimulate and increase economic growth, their use also increases $\mathrm{CO}_{2}$ emissions. This finding supports those of four previous empirical studies conducted on respectively Iran, India, Sub-Saharan Africa and Ghana (e.g., Lotfalipour et al. 2010; Rasool et al. 2019; Tsai et al. 2016; Abokyi et al. 2019), which confirmed the impact of consumption of oil, natural gas, and coal on carbon emissions and also that higher consumption of oil, natural gas, and coal increases economic growth but damages the environment.

Since the industrial revolution the burning of oil, coal, and gas has increased exponentially over time, which in turn significantly raised the levels of $\mathrm{CO}_{2}$ in the atmosphere - also considering that $\mathrm{CO}_{2}$ is not only one of the most important air pollutants in the world, but also the most damaging of the environment and human health. As previously indicated, consumption of oil, natural gas, and coal is not only the major contributors of air pollution in Russia, but it also contributes a pivotal part in the global carbon cycle because it covers one-eighth of the world's land area and also the largest area of the earth (Kudeyarov 2018). In addition, $\mathrm{CO}_{2}$ emissions not only impacts negatively on air pollution and the climate but also affect human health, as reported by Wang et al. (2019) in respect of Pakistan. Our findings correspond with and support those of several recent empirical studies, especially those conducted by Yu et al. (2020) on China; Muhammad (2019) on Middle Eastern and North African 
countries; and Adjei et al. (2019) on African countries, which all confirm high rates of economic growth, fossil fuel energy consumption, and carbon emissions.

Similarly, the empirical study of Fosten (2019) analyzed monthly observations from January 1973 to December 2018 and included the $\mathrm{CO}_{2}$ emissions by source, subdivided into respectively the consumption of oil, coal, and natural gas. Our study, however, contradicts the findings of the earlier survey of Lotfalipour et al. (2010b) on Iran (using 1967-2007 data), which concluded that there is no long-term bond amid fossil fuel consumption, economic growth, and $\mathrm{CO}_{2}$ emissions. Also, as indicated in the research of Valadkhani et al. (2019b), who investigated how utilization of oil, coal, and natural gas contribute to change, $\mathrm{CO}_{2}$ emissions can be reduced along with progress and economic growth.

Russia is an energy-independent economy, a fact confirmed by our results that indicate unidirectional causality from output growth to the growth of energy consumption over the long term. Obviously, this trend causes increased economic growth and fossil fuel consumption, including negative climate effects such as air pollution. However, Russia is in a favorable position - more so than several other countries to reduce $\mathrm{CO}_{2}$ emissions. Our results correspond with those of Rasool et al. (2019) and Mirza and Kanwal (2017), who also researched the causality amidst economic growth, energy consumption, and $\mathrm{CO}_{2}$ emissions in Pakistan. They confirmed bivariate Johansen-Juselius co-integration, applied error correction models to carry out the analysis, and confirmed the stableness of the co-integration results by using the ARDL bounds testing approach. Similarly, the findings of our research study also correspond with those of Kamran et al. (2019) who, in respect of Pakistan, concluded that energy use, financial growth, trade, foreign direct investment, economic, social globalization, and political globalization have positive effects on $\mathrm{CO}_{2}$ emissions, but that urbanization, economic growth, and innovation have negative effects on $\mathrm{CO}_{2}$ emissions.

In the case of Russia, the coefficient for the dependent variable $\mathrm{CO}_{2}$ emissions a statistically significant positive effect regarding the independent variables of economic growth and fossil fuel consumption. This means that environmental degradation is dependent on energy consumption for Russia's rapid economic growth. The result confirms that oil has a positive relation to carbon emissions. At 0.154 percent, oil produces carbon emissions in the environment. The outcomes also indicate that coal has a positive correlation with the environment. Like oil, if coal consumption increases, it will increase pollution in the environment. The same applies to natural gas, as the results confirm a positive correlation with pollution, meaning that the over-use of natural gas could damage and even destroy a healthy environment.

The results (see Table 5) of short term analysis indicate the coefficient value $(-0.001580)$ of the economic growth variable reflects the existence of a statistically insignificant negative relationship in respect of consumption, but for consumption, the results indicate that oil consumption (0.202508), natural gas consumption (0.526057), and coal consumption (0.315975) have a statistically significant positive impact on $\mathrm{CO}_{2}$ emissions. Therefore, a raised in consumption contributes significantly to energy pollutants, as well as to economic growth. This corresponds with and is confirmed by the findings of 
Shahbaz et al. (2013), which also indicated that utilizations of energy increases carbon emissions and economic growth.

Following the example of Brown et al. (2008), we tested the cumulative sum (CUSUM) and the cumulative sum of squared (CUSUMSQ), which recursively provides residual plots to rectify stable long and short-term relations.

The research findings are depicted in Figure 1.

In the CUSUM and CUSUMSQ plots, the statistical results are all within the critical bounds. This means that all the coefficient estimations are stable and that they fall within the upper and lower critical bounds (at $5 \%$ levels of significance), confirming thus the continuity and stability of the long-term and short-term ties.

\section{Vecm Granger Causality Analysis}

After this, we applied the VECM model for determining the evidence of the long-term and short-term causal connection between variables (Rasool et al. 2019; Wang et al. 2019). Thereafter, we employed Wald statistics to define the VECM Granger causal bond between the variables and to determine the lag difference coefficient and difference. Short-term causality is founded on the joint significance of the first difference variable in the VECM and, by using the Wald test it is possible to calculate Granger causality in the long run. Granger causality is more about the short term. Long-term causality depends on the significance of a long-term interconnection and is tested through the lagged error correction term, which is built from a long-term equilibrium fact.

The following econometric equation of VECM is used in our study's model:

\begin{tabular}{|c|c|c|c|c|c|c|c|c|}
\hline $\begin{array}{l}\Delta \log C_{2}{ }_{t} \\
\Delta \log \operatorname{GDP}_{t} \\
\Delta \log _{t} \mathrm{Oil}_{t} \\
\Delta \log _{\mathrm{Coal}_{t}} \\
\Delta \operatorname{LogNG}_{t}\end{array}$ & $=$ & $\begin{array}{l}\phi_{1} \\
\phi_{2} \\
\phi_{3} \\
\phi_{4} \\
\phi_{5}\end{array}$ & $+\sum_{i-1}^{p}$ & 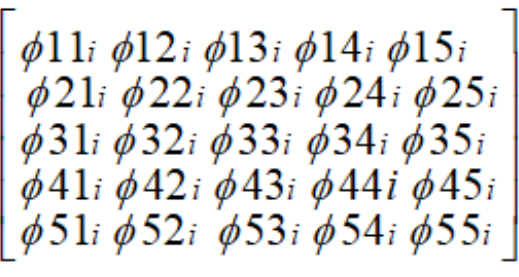 & $\begin{array}{l}\Delta \log C O_{2}{ }_{t-1} \\
\Delta \log \text { SDP }_{t-1} \\
\Delta \log \text { Oil }_{t-1} \\
\Delta \log \text { Coal }_{t-1} \\
\Delta \log N G_{t-1}\end{array}$ & + & $\begin{array}{l}\phi_{1} \\
\varphi_{2} \\
\gamma_{3} \\
\varsigma_{4} \\
\zeta_{5}\end{array}$ & $E C T_{t-1}+$ \\
\hline
\end{tabular}

The next step was to determine the long-term causality through the error correction term (ECT). According to Wang et al. (2019a), if accompanied by a negative sign, then the test measure indicates a significant long-term causal interconnection. The F values estimated by the Wald test assist in explaining the shortterm causality interconnection.

Table 6 indicated the findings of Granger causality test

Our outcomes deepen the presence of a long-term causal relationship between coal, gas and oil use, economic growth, and $\mathrm{CO} 2$ emissions. $\mathrm{ECM}(-1)$ refers to the consumption of coal, gas and oil, $\mathrm{CO}_{2}$ 
emissions, economic growth, and GDP. The long-term feedback hypothesis regarding the relationship between fossil fuel energy use and $\mathrm{CO}_{2}$ emissions postulates that fossil fuel energy use adversely affects the environment. Also, if fossil energy consumption increases, so do countries' economies. Our model shows that increases in GDP and consumption also raise carbon emissions. Our outcomes are in line with those obtained by Pandey and Rastogi (2019), namely that increased fossil fuel energy consumption increases economic growth by strengthening peoples' living requirements, but that it has detrimental impacts on and causes damage to the environment.

In addition, our research confirms the bidirectional causality of fossil energy consumption and $\mathrm{CO}_{2}$ emissions. Over the short term, the VECM Granger causality test confirms that fossil energy consumption Granger causes economic growth and $\mathrm{CO}_{2}$ emissions but that, inversely, in the opposite direction, $\mathrm{CO}_{2}$ emissions do not Granger cause economic growth. The outcomes depict long-term bidirectional causality among fossil energy consumption and economic growth. Our findings support a similar result of Bekun et al. (2019) in respect of South Africa. According to our research, economic growth and carbon dioxide emission exhibit an inverse interconnection, and a unidirectional causality is observed that runs from energy consumption to $\mathrm{CO}_{2}$ emissions.

\section{Conclusion}

Numerous scholars have, through their research, confirmed the connections with fossil fuel energy consumption, economic growth, and carbon emissions. However, our research results provide important insights into additional aspects of the energy economics sector and propose noteworthy policy changes to prevent environmental pollution in Russia. The main target of this study is to testing study the correlation amidst fossil fuel energy consumption, economic growth, and carbon emissions in the Russian context, covering the period from 1990 to 2016. We used the ARDL technique to define the cointegration of the independent variables and $\mathrm{CO}_{2}$ emission as the dependent variable, which has a significant negative correlation with economic growth. Moreover, fossil fuel consumption has a significant positive impact on $\mathrm{CO}_{2}$ emission in terms of both long and short-term dynamics.

Our findings confirm the long-term relationship of fossil fuel energy consumption, economic growth, and $\mathrm{CO}_{2}$ emissions in Russia, in the presence of structural breaks. The study shows that in Russia, economic growth has a significant, negative impact on $\mathrm{CO}_{2}$ emissions across all categories of fossil fuel energy consumption over both the short and the long term. Our results also show that fossil fuel energy consumption increases $\mathrm{CO}_{2}$ emissions and is poor for the climate. In addition, the fast-increasing domestic demand for oil and gas and for coal could increase even more and, due to $\mathrm{CO}_{2}$ emissions, increase and intensify the deterioration of the quality of the environment. The findings also confirm the long-term as well as the short-term relationships of fossil fuel consumption, economic growth, and $\mathrm{CO}_{2}$ emissions in Russia. The overall results reveal that bidirectional Granger causality occurs in the long run among fossil fuel consumption and carbon emission, as well as between fossil fuel consumption and economic growth. 
Moreover, in the short term, utilization of energy causes $\mathrm{CO}_{2}$ emissions. Our results confirm that fossil fuel consumption influences carbon emissions and economic growth, and our findings, therefore, supplement the available literature on the linkage of and relationships among these variables. Presently, the most viable policy option is to limit carbon emissions. It is therefore expected of Russia's government to regulate the traditional resources of energy consumption and, accordingly, as they have already done, to mitigate carbon emissions by allocating resources to the promotion and development of hydropower projects. In fact, the government should promote both hydro and solar projects to improve environmental standards without compromising economic development. It should focus on the green economy, increase carbon taxes, and develop and construct more renewable energy sources.

Consequently, to increase economic growth, the government policymakers should mainly focus on issues in Russia and decrease fossil fuel energy consumption and prioritize renewable energy, rather than merely reducing environmentally damaging impacts, and take on effectual ecological programs to alleviate the adverse pollution impact, whatever its economic growth. Admittedly the present study has some limitations as, among others, it does not fill the causes of $\mathrm{CO}_{2}$ emissions in Russia. However, the objective of our study was limited to the (unidirectional and bidirectional) relationships and impacts of fossil fuel consumption and economic growth on $\mathrm{CO}_{2}$ emissions. As suggested by Zhang and Wang (2018), future research should identify and include other variables to test the proposed model and the spillover influence of economic growth and $\mathrm{CO}_{2}$ emissions in Russia.

\section{Declarations}

\section{Ethics approval and consent to participate: NA}

\section{Consent for publication: NA}

Authors' contributions: OK: Writing original manuscript, data collection, conceptualization ZY: Writing original manuscript MA: Writing original manuscript ZA: Writing review and editing, HM: Writing literature review MM: Writing review and editing, language editing DK: Validation; writing review and editing

Availability of data and material: Data sources and relevant links are provided in the paper to access data.

Competing interests: There is no conflict of interests reported by the authors.

Funding: This research does not receive any funding.

\section{References}

Abas N, Kalair A, Khan N, Kalair AR (2017) Review of GHG emissions in Pakistan compared to SAARC countries. Renew Sustain Energy Rev 80:990-1016. doi: 10.1016/j.rser.2017.04.022 
Abokyi E, Appiah-konadu P, Abokyi F, Oteng-abayie EF (2019) Industrial growth and emissions of CO2 in Ghana: The role of financial development and fossil fuel consumption. Energy Reports 5:1339-1353. doi: 10.1016/j.egyr.2019.09.002

Academy R (2018) Угольная промышленность мира и России period 2000-2017: analysis , trends and prospects , Liudmila Plakitkina. 7-12

Acheampong AO (2018) Economic growth, $\mathrm{CO} 2$ emissions and energy consumption: What causes what and where? Energy Econ 74:677-692. doi: 10.1016/j.eneco.2018.07.022

Adjei I, Sun M, Gao C, et al (2019) Analysis on the nexus of economic growth , fossil fuel energy consumption , CO 2 emissions and oil price in Africa based on a PMG panel ARDL approach. J Clean Prod 228:161-174. doi: 10.1016/j.jclepro.2019.04.281

Ahmad N, Du L (2017) Effects of energy production and CO2emissions on economic growth in Iran: ARDL approach. Energy 123:521-537. doi: 10.1016/j.energy.2017.01.144

Akalpler E, Hove S (2019) Carbon emissions, energy use, real GDP per capita and trade matrix in the Indian economy-an ARDL approach. Energy 168:1081-1093. doi: 10.1016/j.energy.2018.12.012

Al Mamun M, Sohag K, Mia MAH, Uddin GS, Ozturk I (2014) Regional differences in the dynamic linkage between $\mathrm{CO} 2$ emissions, sectoral output and economic growth. Renewable and Sustainable Energy Reviews, 38, 1-11.

Alkhathlan K, Javid M (2013) Energy consumption, carbon emissions and economic growth in saudi arabia: An aggregate and disaggregate analysis. Energy Policy 62:1525-1532. doi:

10.1016/j.enpol.2013.07.068

Anees S, Zaidi H, Hou F, Mirza FM (2018) The role of renewable and non-renewable energy consumption in CO 2 emissions: a disaggregate analysis of Pakistan. 31616-31629

Asafu-Adjaye J, Byrne D, Alvarez M (2016) Economic growth, fossil fuel and non-fossil consumption: A Pooled Mean Group analysis using proxies for capital. Energy Econ 60:345-356. doi:

10.1016/j.eneco.2016.10.016

Bekun FV, Emir F, Sarkodie SA (2019) Another look at the relationship between energy consumption, carbon dioxide emissions, and economic growth in South Africa. Sci Total Environ 655:759-765. doi: 10.1016/j.scitotenv.2018.11.271

Bimanatya TE, Widodo T (2018) Fossil Fuels Consumption , Carbon Emissions, and Economic Growth in Indonesia. 8:90-97

Boussalis C, Coan TG, Poberezhskaya M (2016) Measuring and modeling Russian newspaper coverage of climate change. Glob Environ Chang 41:99-110. doi: 10.1016/j.gloenvcha.2016.09.004 
Bradshaw M (2016) Foreign Investment in the Russian Oil and Gas Industry: Lessons from Sakhalin

Chai J, Du M, Liang T, et al (2019) Coal consumption in China: How to bend down the curve? Energy Econ 80:38-47. doi: 10.1016/j.eneco.2018.12.016

Chen Y, Zhao J, Lai Z, et al (2019) Exploring the effects of economic growth , and renewable and nonrenewable energy consumption on China 's $\mathrm{CO} 2$ emissions: Evidence from a regional panel analysis. Renew Energy 140:341-353. doi: 10.1016/j.renene.2019.03.058

Das PD, Srinivasan PR, Sharfuddin PA (2016) Fossil Fuel Consumption , Carbon Emissions and Temperature Variation in India FOSSIL FUEL CONSUMPTION , CARBON EMISSIONS AND TEMPERATURE VARIATION IN INDIA. doi: 10.1260/0958-305X.22.6.695

Deutch J (2017) Decoupling Economic Growth and Carbon Emissions. Joule 1:3-5. doi: 10.1016/j.joule.2017.08.011

Dickey DA, Fuller WA, Dickey DA, Fuller WA (2012) Distribution of the Estimators for Autoregressive Time Series with a Unit Root Distribution of the Estimators for Autoregressive Time Series With a Unit Root. 1459:. doi: 10.1080/01621459.1979.10482531

Elisa P, Alessandro P, Andrea A, et al (2020) Environmental and climate change impacts of eighteen biomass- based plants in the alpine region: A comparative analysis. J Clean Prod 242:118449. doi: 10.1016/j.jclepro.2019.118449

Fosten J (2019) CO 2 emissions and economic activity: A short-to-medium run perspective. Energy Econ 83:415-429. doi: 10.1016/j.eneco.2019.07.015

Fuinhas JA, Marques AC (2012) Energy consumption and economic growth nexus in Portugal, Italy, Greece, Spain and Turkey: An ARDL bounds test approach (1965-2009). Energy Econ 34:511-517. doi: 10.1016/j.eneco.2011.10.003

Gao J, Kovats S, Vardoulakis S, et al (2018) Science of the Total Environment Public health co-bene fi ts of greenhouse gas emissions reduction: A systematic review. Sci Total Environ 627:388-402. doi: 10.1016/j.scitotenv.2018.01.193

Gorus MS, Aydin M (2019) The relationship between energy consumption, economic growth, and CO 2 emission in MENA countries: Causality analysis in the frequency domain. Energy 168:815-822. doi: 10.1016/j.energy.2018.11.139

Hanif I, Faraz Raza SM, Gago-de-Santos P, Abbas Q (2019) Fossil fuels, foreign direct investment, and economic growth have triggered $\mathrm{CO} 2$ emissions in emerging Asian economies: Some empirical evidence. Energy 171:493-501. doi: 10.1016/j.energy.2019.01.011 
Harker-schuch IEP, Mills FP, Lade SJ, Colvin RM (2020) Computers \& Education C02peration - Structuring a 3D interactive digital game to improve climate literacy in the 12-13-year-old age group. Comput Educ 144:103705. doi: 10.1016/j.compedu.2019.103705

He K, Huo H, Zhang Q, et al (2005) Oil consumption and CO2 emissions in China's road transport: Current status, future trends, and policy implications. Energy Policy 33:1499-1507. doi:

10.1016/j.enpol.2004.01.007

He L, Lu Z, Geng L, et al (2020) Electrical Power and Energy Systems Environmental economic dispatch of integrated regional energy system considering integrated demand response. Electr Power Energy Syst 116:105525. doi: 10.1016/j.jijepes.2019.105525

Heidari H, Turan Katircioğlu S, Saeidpour L (2015) Economic growth, CO2 emissions, and energy consumption in the five ASEAN countries. Int J Electr Power Energy Syst 64:785-791. doi:

10.1016/j.ijepes.2014.07.081

Ifa A, Guetat I (2018) Does public expenditure on education promote Tunisian and Moroccan GDP per capita? ARDL approach. J Financ Data Sci 4:234-246. doi: 10.1016/j.jfds.2018.02.005

Journal S, Statistical R, Series S (2008) Techniques for Testing the Constancy of Regression Relationships over Time Author ( s ): R . L . Brown, J . Durbin, J . M . Evans Published by: Blackwell Publishing for the Royal Statistical Society Stable URL: http://www.jstor.org/stable/2984889. 37:149192

Kamran M, Teng J, Imran M, Owais M (2019) Science of the Total Environment Impact of globalization, economic factors and energy consumption on CO 2 emissions in Pakistan. Sci Total Environ 688:424436. doi: $10.1016 /$ j.scitotenv.2019.06.065

Karatayev M, Clarke ML (2016) A review of current energy systems and green energy potential in Kazakhstan. Renew Sustain Energy Rev 55:491-504. doi: 10.1016/j.rser.2015.10.078

Kibria A, Akhundjanov SB, Oladi R (2019) Fossil fuel share in the energy mix and economic growth. Int Rev Econ Financ 59:253-264. doi: 10.1016/j.iref.2018.09.002

Kivyiro P, Arminen H (2014) Carbon dioxide emissions, energy consumption, economic growth, and foreign direct investment: Causality analysis for Sub-Saharan Africa. Energy 74:595-606. doi: 10.1016/j.energy.2014.07.025

Korppoo A, Institutt FN, Kokorin A (2020) Russia 's 2020 GHG emissions target: Emission trends and implementation Russia 's 2020 GHG emissions target: Emission trends and implementation. doi: $10.1080 / 14693062.2015 .1075373$

Kudeyarov VN (2018) Soil Respiration and Biogenic Carbon Dioxide Sink in the Territory of Russia: An Analytical Review. 51:599-612. doi: 10.1134/S1064229318060091 
Kuznetsov PN, llyushechkin AY Coal resources, production and use in the Russian Federation. Woodhead Publishing Limited

Kwiatkowski D, Phillips PCB (1992) Testing the null hypothesis of stationarity against the alternative of a unit root How sure are we that economic time series have a unit root?*. 54:159-178

Lalesca E, Mansuelo R, Domingos A, et al (2020) The in fl uence of climate change on renewable energy systems designed to achieve zero energy buildings in the present: A case study in the Brazilian Savannah. 52.. doi: 10.1016/j.scs.2019.101843

Lei Y, Li L, Pan D (2014) Study on the relationships between coal consumption and economic growth of the six biggest coal consumption countries: with coal price as a third variable. 61:624-634. doi: 10.1016/j.egypro.2014.11.1185

Lin B, Raza MY (2019) Analysis of energy related CO 2 emissions in Pakistan. J Clean Prod 219:981993. doi: 10.1016/j.jclepro.2019.02.112

Liu M, Huang Y, Jin Z, et al (2017) Estimating health co-bene fi ts of greenhouse gas reduction strategies with a simpli fi ed energy balance based model: The Suzhou City case. J Clean Prod 142:3332-3342. doi: 10.1016/j.jclepro.2016.10.137

Lotfalipour MR, Falahi MA, Ashena M (2010a) Economic growth, CO2 emissions, and fossil fuels consumption in Iran. Energy 35:5115-5120. doi: 10.1016/j.energy.2010.08.004

Lotfalipour MR, Falahi MA, Ashena M (2010b) Economic growth , CO 2 emissions, and fossil fuels consumption in Iran. Energy 35:5115-5120. doi: 10.1016/j.energy.2010.08.004

Makun KK (2018) Imports, remittances, direct foreign investment and economic growth in Republic of the Fiji Islands: An empirical analysis using ARDL approach. Kasetsart J Soc Sci 39:439-447. doi:

10.1016/j.kjss.2017.07.002

Mardani A, Streimikiene D, Cavallaro F, et al (2019) Carbon dioxide (CO 2 ) emissions and economic growth: A systematic review of two decades of research from 1995 to 2017. Sci Total Environ 649:31-49. doi: 10.1016/j.scitotenv.2018.08.229

Mensah IA, Sun M, Gao C, et al (2019) Analysis on the nexus of economic growth, fossil fuel energy consumption, $\mathrm{CO} 2$ emissions and oil price in Africa based on a PMG panel ARDL approach. $J$ Clean Prod 228:161-174. doi: 10.1016/j.jclepro.2019.04.281

Mikayilov JI, Galeotti M, Hasanov FJ (2018) The impact of economic growth on CO2 emissions in Azerbaijan. J Clean Prod 197:1558-1572. doi: 10.1016/j.jclepro.2018.06.269

Mirza FM, Kanwal A (2017) Energy consumption, carbon emissions and economic growth in Pakistan: Dynamic causality analysis. Renew Sustain Energy Rev 72:1233-1240. doi: 10.1016/j.rser.2016.10.081 
Mohamed H, Ben Jebli M, Ben Youssef S (2019) Renewable and fossil energy, terrorism, economic growth, and trade: Evidence from France. Renew Energy 139:459-467. doi: 10.1016/j.renene.2019.02.096

Muhammad B (2019) Energy consumption, CO2 emissions and economic growth in developed, emerging and Middle East and North Africa countries. Energy 179:232-245. doi:

10.1016/j.energy.2019.03.126

Nkoro E, Uko AK (2001) ARDL için ayrıntılı bir döküman. J Stat Econom Methods 5:63-91. doi: $10.1002 /$ jae.616

Orazalin N, Mahmood M (2018) Economic, environmental , and social performance indicators of sustainability reporting: Evidence from the Russian oil and gas industry. Energy Policy 121:70-79. doi: 10.1016/j.enpol.2018.06.015

Ouyang X, Shao Q, Zhu X, et al (2019) Science of the Total Environment Environmental regulation, economic growth and air pollution: Panel threshold analysis for OECD countries. Sci Total Environ 657:234-241. doi: 10.1016/j.scitotenv.2018.12.056

Overland I (2017) The Hunter Becomes the Hunted: Gazprom Encounters EU Regulation The Hunter Becomes the Hunted: Gazprom Encounters EU Regulation. doi: 10.1057/978-1-137-59104-3

Ozturk I, Acaravci A (2010) CO2 emissions, energy consumption and economic growth in Turkey. Renewable and Sustainable Energy Reviews, 14(9), 3220-3225.

Ozturk I, Aslan A, Kalyoncu H (2010) Energy consumption and economic growth relationship: Evidence from panel data for low and middle income countries. Energy Policy, 38(8), 4422-4428.

Pandey KK, Rastogi H (2019) Effect of energy consumption \& economic growth on environmental degradation in India: A time series modelling. Energy Procedia 158:4232-4237. doi:

10.1016/j.egypro.2019.01.804

Pao H, Yu H, Yang Y (2011) Modeling the CO 2 emissions, energy use, and economic growth in Russia. Energy 36:5094-5100. doi: 10.1016/j.energy.2011.06.004

Pesaran MH (2008) An Autoregressive Distributed-Lag Modelling Approach to Cointegration Analysis. In: Econometrics and Economic Theory in the 20th Century: The Ragnar Frisch Centennial Symposium. pp $371-413$

Rasool Y, Anees S, Zaidi H, Zafar MW (2019) Determinants of carbon emissions in Pakistan 's transport sector. Environ Sci Pollut Res 1-15

Rauf A, Zhang J, Li J, Amin W (2018) Structural changes, energy consumption and carbon emissions in China: Empirical evidence from ARDL bound testing model. Struct Chang Econ Dyn 47:194-206. doi: 10.1016/j.strueco.2018.08.010 
Requia WJ, Mohamed M, Higgins CD, et al (2018) How clean are electric vehicles? Evidence-based review of the e ff ects of electric mobility on air pollutants, greenhouse gas emissions and human health. Atmos Environ 185:64-77. doi: 10.1016/j.atmosenv.2018.04.040

Saboori B, Sulaiman J (2013) Environmental degradation, economic growth and energy consumption: Evidence of the environmental Kuznets curve in Malaysia. Energy Policy 60:892-905. doi:

10.1016/j.enpol.2013.05.099

Saidi K, Hammami S (2015) The impact of CO2 emissions and economic growth on energy consumption in 58 countries. Energy Reports 1:62-70. doi: 10.1016/j.egyr.2015.01.003

Salahuddin M, Alam K, Ozturk I, Sohag K (2018) The effects of electricity consumption, economic growth, financial development and foreign direct investment on $\mathrm{CO} 2$ emissions in Kuwait. Renewable and Sustainable Energy Reviews, 81, 2002-2010.

Sanz MT, Cansino JM, González-Limón JM, et al (2014) Economic assessment of CO2 emissions savings in Spain associated with the use of biofuels for the transport sector in 2010. Util Policy 29:25-32. doi: 10.1016/j.jup.2014.04.002

Shahbaz M, Muhammad Q, Hye A, et al (2013) Economic growth, energy consumption , fi nancial development, international trade and CO 2 emissions in Indonesia. Renew Sustain Energy Rev 25:109121. doi: 10.1016/j.rser.2013.04.009

Shvarts EA, Pakhalov AM, Yu A (2016) Assessment of environmental responsibility of oil and gas companies in Russia: the rating method. J Clean Prod 127:143-151. doi: 10.1016/j.jclepro.2016.04.021

Sims (1980) Vector Autoregression and Vector Error-Correction Models. Chapter 5 70-99

Tang CF, Tan BW, Ozturk I (2016) Energy consumption and economic growth in Vietnam. Renewable and Sustainable Energy Reviews, 54, 1506-1514.

Tsai B, Chang C, Chang C (2016) Elucidating the consumption and CO 2 emissions of fossil fuels and low-carbon energy in the United States using Lotka e Volterra models. Energy 100:416-424. doi: 10.1016/j.energy.2015.12.045

Valadkhani A, Nguyen J, Bowden M (2019a) Pathways to reduce CO 2 emissions as countries proceed through stages of economic development. Energy Policy 129:268-278. doi: 10.1016/j.enpol.2019.02.024

Valadkhani A, Nguyen J, Bowden M (2019b) Pathways to reduce CO 2 emissions as countries proceed

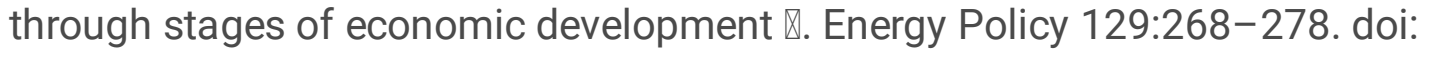

10.1016/j.enpol.2019.02.024

Waheed R, Sarwar S, Wei C (2019) The survey of economic growth, energy consumption and carbon emission. Energy Reports 5:1103-1115. doi: 10.1016/j.egyr.2019.07.006 
Wang Z, Asghar MM, Zaidi SAH, Wang B (2019a) Dynamic linkages among CO 2 emissions, health expenditures, and economic growth: empirical evidence from Pakistan. Environ Sci Pollut Res. doi: $10.1007 / \mathrm{s} 11356-019-04876-x$

Wang Z, Rasool Y, Asghar MM, Wang B (2019b) Dynamic linkages among CO 2 emissions, human development, financial development, and globalization: empirical evidence based on PMG long-run panel estimation. Environ Sci Pollut Res 26:

Wang Z, Rasool Y, Zhang B, et al (2019c) Dynamic linkage among industrialisation, urbanisation, and CO2 emissions in APEC realms: evidence based on DSUR estimation. Struct Chang Econ Dyn. doi: 10.1016/j.strueco.2019.12.001

Wesseh PK, Lin B (2018) Energy consumption, fuel substitution, technical change, and economic growth: Implications for CO2 mitigation in Egypt. Energy Policy 117:340-347. doi: 10.1016/j.enpol.2018.03.022

Yu X, Zheng H, Sun L, Shan Y (2020) An emissions accounting framework for industrial parks in China. J Clean Prod 244:118712. doi: 10.1016/j.jclepro.2019.118712

Yue W, Jingyou W, Mei Z, Lei SHI (2019) ScienceDirect ScienceDirect Spatial Correlation Analysis of Energy Consumption and Air Pollution in Beijing-Tianjin-Hebei Region Pollution in Beijing-Tianjin-Hebei Region Assessing the feasibility of using the heat demand-outdoor temperature function a lo. Energy Procedia 158:4280-4285. doi: 10.1016/j.egypro.2019.01.797

Zhang B, Wang Z (2018) Energy production, economic growth and CO 2 emission: evidence from Pakistan. Nat Hazards 90:27-50. doi: 10.1007/s11069-017-3031-z

Zhang L, Shen Q, Wang M, et al (2019) Driving factors and predictions of CO 2 emission in China's coal chemical industry. J Clean Prod 210:1131-1140. doi: 10.1016/j.jclepro.2018.10.352

\section{Tables}


Table 1. Variables and Definitions

\begin{tabular}{lll} 
Variable & $\begin{array}{l}\text { Unit of } \\
\text { measurement }\end{array}$ & Definition \\
\hline $\begin{array}{l}\text { Economic } \\
\text { growth }\end{array}$ & $\begin{array}{l}\text { GDP per capita } \\
\text { (US Dollar) }\end{array}$ & $\begin{array}{l}\text { It is the value of gross domestic product divided by population } \\
\text { to get per capita GDP. }\end{array}$ \\
\hline $\begin{array}{l}\text { Oil } \\
\text { consumption }\end{array}$ & Million tones & $\begin{array}{l}\text { It is production statistics are consumption of petroleum fuels } \\
\text { in Russia }\end{array}$ \\
\hline Carbon dioxide & $\begin{array}{l}\text { Metric tones per } \\
\text { capita }\end{array}$ & $\begin{array}{l}\text { The carbon emissions released from using coal, oil, and } \\
\text { natural gas in Russia }\end{array}$ \\
\hline $\begin{array}{l}\text { Natural Gas } \\
\text { consumption }\end{array}$ & Million tones & $\begin{array}{l}\text { It is the consumption statistics are stocks at storage facilities } \\
\text { and liquefaction plants in Russia }\end{array}$ \\
\hline $\begin{array}{l}\text { Coal } \\
\text { Consumption }\end{array}$ & Million tones & It is statistics consumption coal in Russia \\
\hline
\end{tabular}

Data of all the variables sought from World Development Indicators (World Bank 2017). The data ranges from 1990 to 2016.

\begin{tabular}{|c|c|c|c|c|}
\hline \multirow[b]{2}{*}{ Variables } & \multicolumn{2}{|l|}{ At level } & \multicolumn{2}{|c|}{ First different } \\
\hline & t- statistic & Probability & t- statistic & Probability \\
\hline $\mathrm{LCO}_{2}$ & -1.381248 & 0.1511 & -3.028906 & 0.0458 \\
\hline LOil & -5.731947 & 0.0001 & -2.728372 & 0.0834 \\
\hline LCoal & -3.766935 & 0.0088 & -3.276218 & 0.0277 \\
\hline LGDP & -1.478783 & 0.5282 & -5.899627 & 0.0001 \\
\hline LNatural Gas & -1.461938 & 0.5365 & -4.911086 & 0.0006 \\
\hline
\end{tabular}




\begin{tabular}{|llllll|}
\hline \multicolumn{4}{|l|}{ Table 3. Descriptive statistic } & & \\
& LOGCO $_{2}$ & LOG_OIL & LOGCOAL & LOGEG & LOGNG \\
\hline Mean & 3.206007 & 2.164028 & 2.030315 & 0.660893 & 2.546096 \\
\hline Median & 3.185762 & 2.124772 & 2.004994 & 0.720907 & 2.549769 \\
\hline Maximum & 3.353806 & 2.400942 & 2.260800 & 1.163413 & 2.582188 \\
\hline Minimum & 3.165578 & 2.086600 & 1.941061 & -0.389781 & 2.485606 \\
\hline Std. Dev. & 0.054246 & 0.093461 & 0.085791 & 0.353349 & 0.027654 \\
\hline
\end{tabular}

\begin{tabular}{|l|lll|}
\hline \multicolumn{2}{|l}{ Table 4: Co-integration results of Bound testing } & & \\
\hline Investigated model & Optimal lag & F-statistic & Remarks \\
\hline $\mathrm{CO}_{2}=\mathrm{f}(\mathrm{GDP}$, Oil, Coal, Natural gas) & $2,1,1,1,2$ & 6.710269 \\
\hline Level of significant & $\mathrm{I}(0)$ Bound & $\mathrm{I}(1)$ Bound \\
\hline $10 \%$ & 2.2 & 3.09 \\
\hline $5 \%$ & 2.56 & 3.49 \\
\hline $2.5 \%$ & 2.88 & 3.87 \\
\hline $1 \%$ & 3.29 & 4.37 \\
\hline
\end{tabular}




\begin{tabular}{|c|c|c|c|c|}
\hline Variable & Coefficient & Std. Error & T-Statistic & Probability \\
\hline C & $0.674877^{a}$ & 0.136129 & 4.957639 & 0.0003 \\
\hline LOG_OIL & $0.154073^{a}$ & 0.031490 & 4.892721 & 0.0003 \\
\hline LOGCOAL & $0.430276^{a}$ & 0.035492 & 12.123345 & 0.0000 \\
\hline LOGEG & $-0.010824^{b}$ & 0.004642 & -2.331471 & 0.0365 \\
\hline \multirow[t]{2}{*}{ LOGNG } & $0.521699^{a}$ & 0.054149 & 9.634427 & 0.0000 \\
\hline & \multicolumn{4}{|l|}{ Short term analysis } \\
\hline Variable & Coefficient & Std. Error & T-Statistic & Probability \\
\hline LOG_OIL & $0.202508^{a}$ & 0.015293 & 13.242228 & 0.0000 \\
\hline LOGCOAL & $0.315975^{a}$ & 0.013677 & 23.102765 & 0.0000 \\
\hline LOGEG & $-0.001580^{c}$ & 0.000880 & -1.795457 & 0.0959 \\
\hline LOGNG & $0.526057^{a}$ & 0.020939 & 25.123109 & 0.0000 \\
\hline CointEq(-1) & $-0.572290^{a}$ & 0.076649 & -7.466382 & 0.0000 \\
\hline \multicolumn{5}{|l|}{ Diagnostic tests } \\
\hline R squared & 0.998228 & & & \\
\hline Adjusted R squared & 0.997905 & & & \\
\hline S.E. of regression & 0.002483 & & & \\
\hline Sum squared resid & 0.000136 & & & \\
\hline Log likelihood & 126.4104 & & & \\
\hline F-statistic & 3097.653 & & & \\
\hline Prob (F-statistic) & 0.000000 & & & \\
\hline Durbin-Watson stat (DW) & 2.004330 & & & \\
\hline Х2 ARCH & $0.214518(0.6808)$ & & & \\
\hline$\chi^{2}$ LM & $0.392041(0.6808)$ & & & \\
\hline Х2 RESET & $0.369644(0.7153)$ & & & \\
\hline
\end{tabular}

a show the $1 \%$ significant, ${ }^{b}$ indicate the $5 \%$ significant, ${ }^{c}$ ratify the $10 \%$ significant 


\begin{tabular}{|c|c|c|c|c|c|c|}
\hline Variables & $\log \mathrm{CO}_{2}$ & Log Oil & Log GDP & Log Coal & $\log N G$ & $\operatorname{ECM}(-1)$ \\
\hline \multirow[t]{2}{*}{$\log \mathrm{CO}_{2}$} & $\longrightarrow$ & 1.699540 & 1.236088 & -0.247516 & 0.966098 & $-1.420558^{* *}$ \\
\hline & & $(0.1064)$ & $(0.2323)$ & $(0.8073)$ & $(0.3468)$ & $(0.0358)$ \\
\hline \multirow[t]{2}{*}{ Log Oil } & -1.333048 & - & $4.672031^{*}$ & -0.348204 & 1.848042 & $0.286690^{*}$ \\
\hline & $(0.1991)$ & & $(0.0002)$ & $(0.7317)$ & $(0.0811)$ & $(0.0000)$ \\
\hline \multirow[t]{2}{*}{ Log GDP } & 0.679565 & 2.028757 & $\longrightarrow$ & 0.713527 & 0.539726 & $-1.140200^{* *}$ \\
\hline & $(0.5253)$ & $(0.1742)$ & & $(0.5096)$ & $(0.5964)$ & $(0.0451)$ \\
\hline \multirow[t]{2}{*}{ Log Coal } & $3.309245^{\star * *}$ & $3.362661^{\star \star *}$ & $3.866150^{\star \star \star}$ & . & $3.750875^{\star \star k}$ & $-2.446960^{*}$ \\
\hline & $(0.0717)$ & $(0.0693)$ & $(0.0506)$ & & $(0.0543)$ & $(0.0143)$ \\
\hline \multirow[t]{2}{*}{ Log NG } & 0.689638 & 1.228732 & 0.052548 & 0.268531 & $\longrightarrow$ & -0.253032 \\
\hline & $(0.5206)$ & $(0.3270)$ & $(0.9490)$ & $(0.7690)$ & & $(0.7720)$ \\
\hline \multicolumn{7}{|c|}{ *shows the $1 \%$ significance, } \\
\hline \multicolumn{7}{|c|}{ ** indicates the $5 \%$ significance, } \\
\hline \multicolumn{7}{|c|}{ *** denotes the $10 \%$ significance } \\
\hline \multicolumn{7}{|c|}{ T-stat values and p-values are reported } \\
\hline
\end{tabular}

\section{Figures}




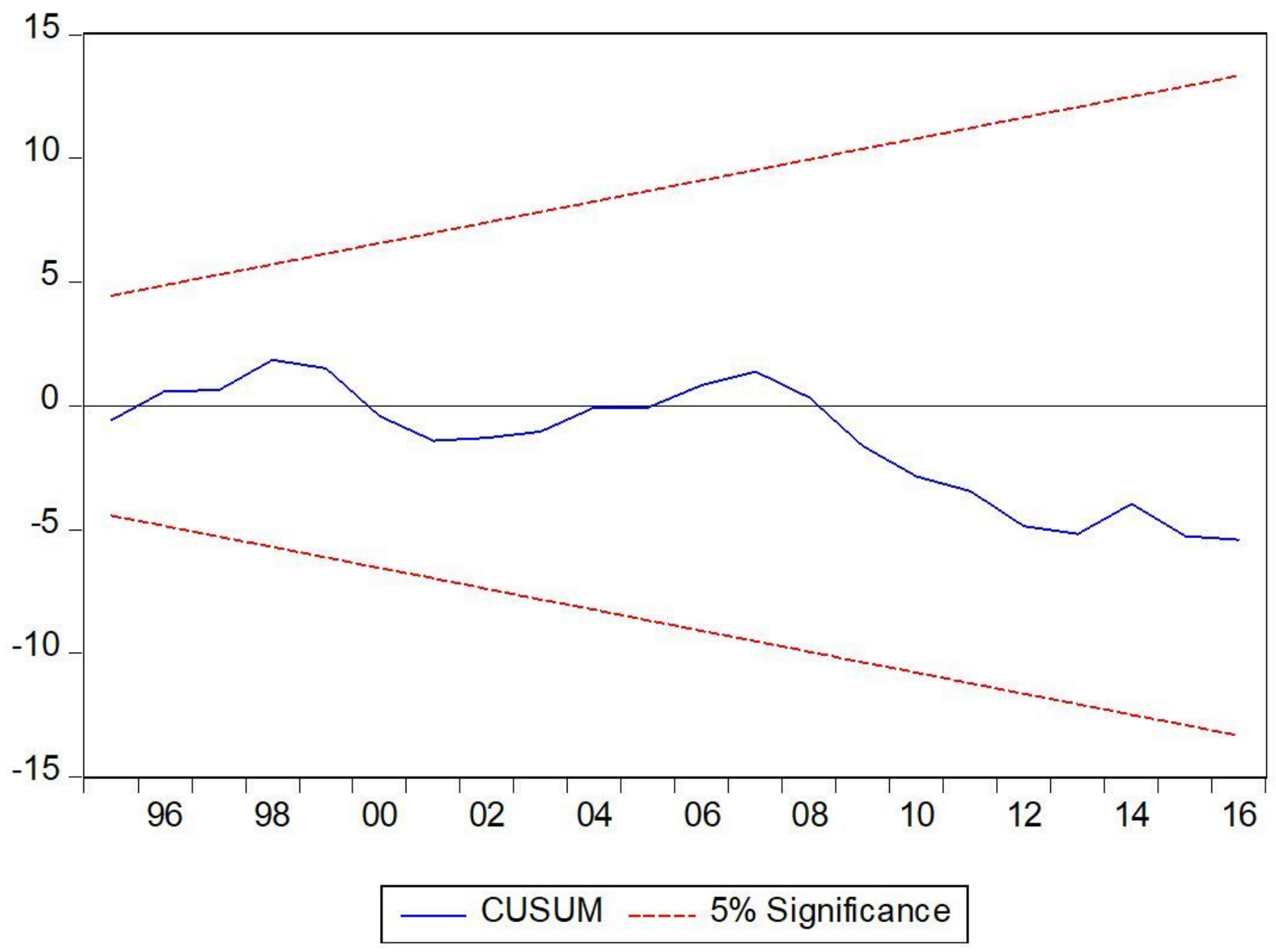

Figure 1

Plot of CUSUM 


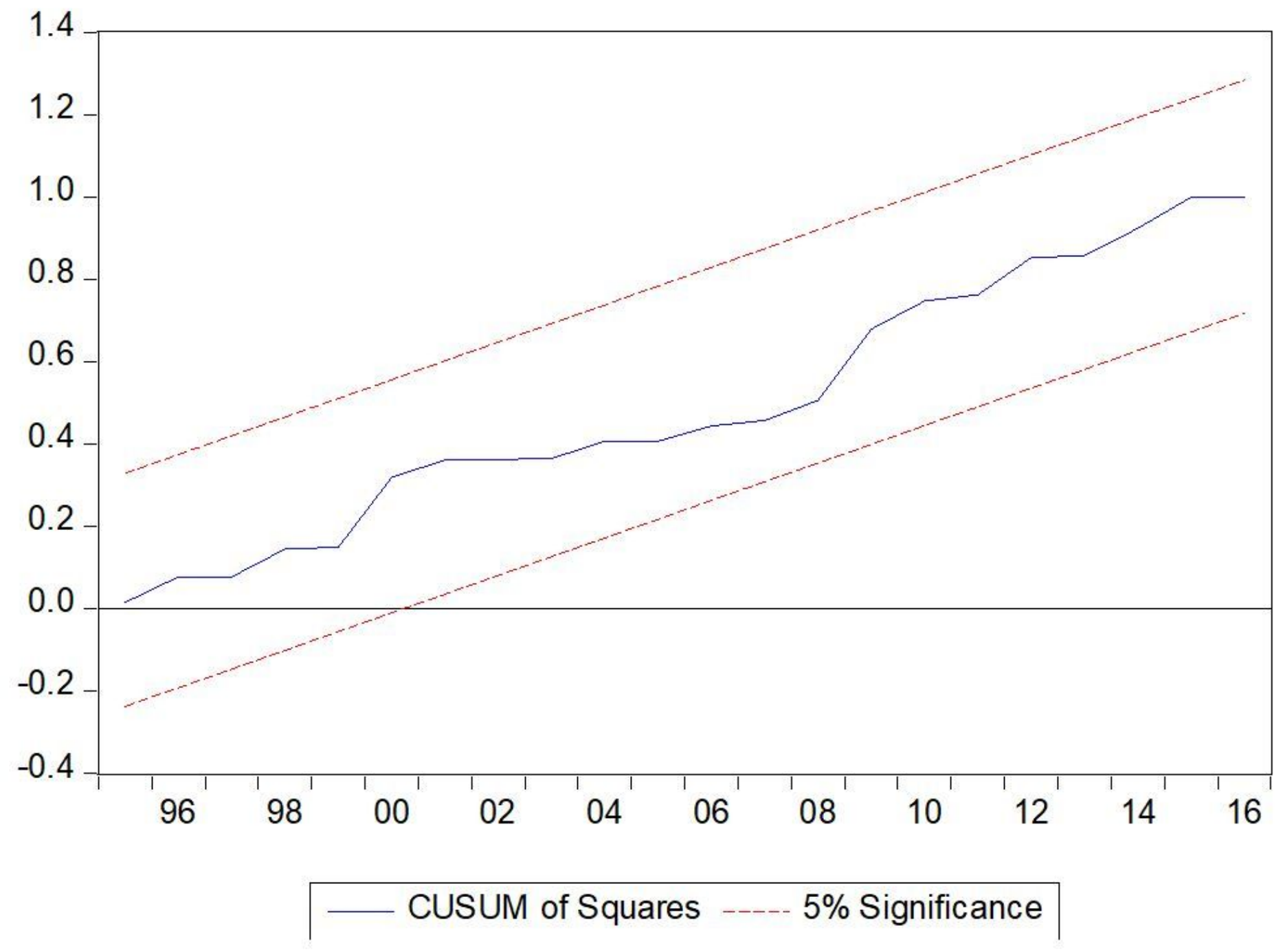

Figure 2

Plot of CUSUMsq 